\title{
Efek Pemberian Asam Alfa Lipoat terhadap Kadar MDA dan Gambaran Histologi pada Hati Tikus Wistar Jantan dengan Diabetes Melitus Tipe 1
}

\section{Effect of Alpha Lipoic Acid Administration on MDA Levels and Liver Histology of Male Wistar Rats with Type 1 Diabetes Mellitus}

\author{
Nur Lailatul F $F^{1}$, Diana Lyrawati', Mudjiwijono Handaru \\ ${ }^{1}$ Program Studi Ilmu Farmasi Fakultas Kedokteran Universitas Brawijaya Malang \\ ${ }^{2}$ Laboratorium Ilmu Farmasi Fakultas Kedokteran Universitas Brawijaya Malang \\ ${ }^{3}$ Laboratorium Patalogi Anatomi Fakultas Kedokteran Universitas Brawijaya Malang
}

\begin{abstract}
ABSTRAK
Diabetes melitus dan komplikasinya disebabkan oleh hiperglikemia yang menyebabkan stres oksidatif melalui produksi spesies oksigen reaktif (ROS). Asam Alfa Lipoat (ALA) terbukti dalam mengatasi stres oksidatif yang menyebabkan komplikasi vaskular pada diabetes. Penelitian ini bertujuan untuk mengetahui efek ALA terhadap kadar malondialdehid (MDA) dan gambaran histologi hati tikus diabetes mellitus tipe 1. Rancangan penelitian ini menggunakan true experimental design dan posttest only control group. Tiga puluh ekor tikus jantan (Rattus norvegicus galur wistar) dibagi menjadi lima kelompok yaitu: kelompok tikus normal, tikus diabetes, tikus diabetes dengan ALA dosis $80 \mathrm{mg} / \mathrm{kgBB} /$ hari, tikus diabetes dengan ALA dosis $200 \mathrm{mg} / \mathrm{kgBB} / \mathrm{hari}$, dan tikus diabetes dengan ALA dosis $500 \mathrm{mg} / \mathrm{kg} /$ hari. ALA diberikan sehari sekali secara oral. Induksi diabetes pada tikus dilakukan secara intraperitonial dosis tunggal streptozotocin $60 \mathrm{mg} / \mathrm{kgBB}$. Kadar MDA pada hati diukur dengan metode spektrofotometri dan histologi hati diuji setelah diwarnai dengan hematoksilin dan eosin. Pada penelitian ini, ALA dosis 80 dan 200mg/kgBB/hari tidak memberikan pengaruh terhadap kadar MDA, namun terjadi perbaikan gambaran histologi, warna hati, dan penurunan perlemakan pada hepatosit dibandingkan tikus diabetes. Pada dosis ALA 500mg/kgBB/hari menunjukkan warna hati lebih pucat, peningkatan perlemakan pada hepatosit, dan tingkat kematian yang tinggi. Kesimpulan dari penelitian ini, pemberian ALA selama 4 minggu tidak berpengaruh terhadap kadar MDA, namun memperbaiki gambaran histologi hati tikus.
\end{abstract}

Kata Kunci: Asam alfa lipoat, diabetes mellitus tipe 1, histologi hati, malondialdehid, perlemakan hepatosit

\begin{abstract}
Diabetes mellitus and its complication induced by hyperglycemia cause oxidative stress through reactive oxygen species (ROS) production. Alpha Lipoic Acid (ALA) is proven to overcome oxidative stress that causes vascular complications in diabetes. This study aims to determine effects of ALA on malondialdehyde (MDA) content and liver histology in diabetic liver of male wistar rats. This study used true experimental design and posttest only control group. 30 male rats were divided into 5 groups: normal rats, diabetic rats, diabetic rats with ALA $80 \mathrm{mg} / \mathrm{kgBW} / \mathrm{d}$, diabetic rats with ALA $200 \mathrm{mg} / \mathrm{kgBW} / \mathrm{d}$, and diabetic rats with ALA 500 mg/ $\mathrm{kgBW} / \mathrm{d}$. ALA was given orallyonce a day. Diabetes was induced in rats by single intraperitoneal injection of $60 \mathrm{mg} / \mathrm{kgBWstreptozotocin} \mathrm{(STZ).} \mathrm{The} \mathrm{content} \mathrm{of} \mathrm{MDA} \mathrm{was} \mathrm{measured} \mathrm{using}$ spectrophotometric assay and liver histology was assessed by staining with hematoxylin-eosin. In this study, ALA dose of 80 and $200 \mathrm{mg} / \mathrm{kgBW} / \mathrm{d}$ showed no effect in MDA content but occurred improved liver histology, liver color, and decreased fatty in hepatocytes compared to diabetic rats. ALA dose of $500 \mathrm{mg} / \mathrm{kgBW} / \mathrm{d}$ showed paler liver, increased fatty in hepatocytes, and increased mortality rate in diabetic rats. In conclusion, the findings of the present experimental study indicate ALA administrationfor 4 weeksdid not reduce MDA content, yet improved the liver histology.
\end{abstract}

Keywords: Alpha lipoic acid, fatty in hepatocytes, liver histology, malondialdehyde, type 1 diabetes mellitus

Jurnal Kedokteran Brawijaya, Vol. 28, No. 3, Februari 2015; Korespondensi: Diana Lyrawati. Laboratorium Farmasi Fakultas Kedokteran Universitas Brawijaya Malang, Jl. Veteran Malang Tel. (0341)566117Email:eldi_7_98@yahoo.com 


\section{PENDAHULUAN}

Komplikasi pada diabetes mellitus (DM) disebabkan oleh hiperglikemia yang menyebabkan stres oksidatif melalui peningkatan produksi radikal bebas terutama spesies oksigen reaktif (ROS) (1). Peningkatan produksi ROS yang terlibat dalam komplikasi diabetes melalui proses, di antaranya peningkatan jalur poliol, peningkatan jalur heksoamin, produksi AGE (advanced-glycation end products), dan aktivasi protein kinase C (PKC) (2). Reaksi radikal dengan lipid disebut peroksidasi lipid terjadi pada tahap akhir proses stres oksidatif dan berperan dalam patogenesis penyakit pada manusia (3). Stres oksidatif dan tingkat komplikasi yang ditimbulkan oleh stres oksidatif pasien DM tipe 1 lebih tinggi dibandingkan pasien DM tipe 2 (4).

Produksi radikal bebas secara tidak langsung dinilai dengan kadar peroksidasi lipid (2). Malondialdehid (MDA) dalam sel dihasilkan dari proses peroksidasi lipid yang diukur menggunakan metode Thiobarbituric AcidReactive Subtance (TBARS) (5). Pasien dengan diabetes mempunyai prevalensi tinggi untuk kelainan hati, termasuk enzim hati yang abnormal, nonalcoholic fatty liver disease (NAFLD), sirosis, karsinoma, dan gagal hati akut. Hati merupakan organ yang penting dalam memelihara kadar glukosa darah dalam batas normal, sehingga peningkatan glukosa darah akan menyebabkan ketidakseimbangan reaksi oksidasi dan reduksi di hepatosit dan detoksifikasi, yang berpengaruh dalam reaksi radikal bebas dan banyak penyakit penanda stres $(6,7)$. Keterlibatan proses oksidasi pada DM menunjukkan bahwa penurunan kadar glukosa darah belum cukup untuk mengatasi komplikasi dari diabetes. Diperlukan obat yang mempunyai efek antioksidan dan dapat menurunkan kadar glukosa darah.

Antioksidan, seperti vitamin C, E, dan asam alfa lipoat (ALA) telah terbukti secara eksperimental maupun klinis dalam mengatasi stres oksidatif yang menyebabkan komplikasi vaskular pada diabetes (8). Disisi lain, vitamin C dan E yang bereaksi dengan radikal bebas akan menjadi teroksidasi yang lebih lanjut menyebabkan penurunan fungsi antioksidan tersebut. Aktivitas antioksidan ALA baik dalam bentuk redoks dan mampu mengembalikan aktivitas antioksidan (vitamin C, E, dan glutation) dengan meregenerasi antioksidan tersebut (9). Dosis ALA yang digunakan secara klinis 600-1800mg 1-3x sehari dapat menurunkan kadar plasma peroksida lemak, menurunkan gejala neuropati, dan meningkatkan sensitivitas insulin pada diabetes tipe 2 (10).

Penelitian sebelumnya meneliti pengaruh ALA pada hati dengan diet 500mg/kg dengan tikus yang diinduksi streptozotocin (STZ) menunjukkan pengaruh pada stres oksidatif (11). Hubungan antara dosis dengan respon diketahui dari penelitian ALA dalam mengatasi neuropati pada hewan coba. Penelitian lebih lanjut perlu dilakukan untuk menilai efek ALA terhadap stres oksidatif pada hati tikus diabetes berdasarkan perbedaan dosis. Penelitian dilakukan dengan menilai parameter peroksidasi lipid yaitu MDA dan gambaran histologi hati pada tikus wistar diabetes yang diinduksi streptozotocin yang mendapatkan suplemen ALA pada dosis $80 \mathrm{mg} / \mathrm{kg} /$ hari, $200 \mathrm{mg} / \mathrm{kg} /$ hari, dan $500 \mathrm{mg} / \mathrm{kg} /$ hari (12-14). Tujuan penelitian ini, yaitu untuk mengetahui efek suplemen ALA terhadap kadar MDA dan gambaran histologi pada hati tikus diabetes mellitus tipe 1 pada masing-masing dosis setelah diberikan dalam jangka waktu singkat selama empat minggu.

\section{METODE}

\section{Desain Penelitian}

Penelitian ini merupakan penelitian ekperimental laboratorik yang menggunakan metode post test only control group. Hewan coba dibagi menjadi 5 kelompok, kelompok I: tikus normal tanpa perlakuan ALA (NTA), kelompok II: tikus diabetes tanpa perlakuan ALA (DTA), Kelompok III: tikus diabetes dengan ALA dosis $80 \mathrm{mg} / \mathrm{kg} / \mathrm{hari}$ (DA80), Kelompok IV: tikus diabetes dengan ALA dosis $200 \mathrm{mg} / \mathrm{kg} / \mathrm{hari}$ (DA200), dan kelompok V: tikus diabetes dengan ALA dosis $500 \mathrm{mg} / \mathrm{kg} / \mathrm{hari}$. Dosis ALA yang digunakan pada penelitian ini mengacu pada hasil penelitian terdahulu (3).

\section{Hewan Coba}

Hewan coba yang digunakan adalah tikus putih (Rattus norvegicus var. Wistar) jantan dengan usia 75-90 hari dan berat $180-300$ gram. Hewan coba yang digunakan pada penelitian ini berjumlah 30 ekor dimana masing-masing kelompok menggunakan 6 ekor hewan coba. Semua perlakuan pada hewan coba telah disetujui oleh Komisi Etik Penelitian Kesehatan Fakultas Kedokteran Universitas Brawijaya dengan keterangan kelaikan etik nomor 231/EC/KEPK-S1-FARM/03/2014.

\section{Induksi Diabetes Mellitus Tipe 1}

Tikus dipuasakan selama \pm 20 jam. Tikus diinjeksi streptozotocin dosis tunggal $60 \mathrm{mg} / \mathrm{kg}$ secara intraperitonial. Glukosa darah puasa diukur setelah tiga hari injeksi. Penetapan diabetes mellitus jika glukosa darah $>200 \mathrm{mg} / \mathrm{dl}$.

\section{Pemberian Suplemen ALA}

Suplemen ALA yang dipilih adalah Thioctic Acid berbentuk serbuk yang berasal dari Jiangsu Tohope Pharmaceutical CO., LTD, Changshu, Cina. ALA diberikan pada kelompok III, IV, dan $\mathrm{V}$ selama empat minggu yang dimulai tujuh hari sejak awitan diabetes. Pemilihan durasi selama empat minggu untuk megobservasi efek penggunaan ALA dalam jangka waktu singkat (15). Preparasi asam alfa lipoat dilarutkan dalam minyak zaitun (16).

\section{Pengambilan Organ Hati}

Tikus dieutanasia setelah diberikan suplemen ALA selama empat minggu dengan inhalasi eter (17). Organ dicuci dan diperfusi dengan PBS hingga darah berhenti mengalir. Hati kemudian dipisah untuk pengukuran MDA dan pengamatan histologi.

\section{Pembuatan Preparat Histologi}

Jaringan dipilih dipotong dengan ketebalan $\pm 2-3 \mathrm{~mm}$, lalu dimasukkan kedalam kaset histologi dan direndam dalam larutan formalin $10 \%$. Selanjutnya, jaringan diproses menggunakan mesin Tissue Tex Processor dan mengalami proses pencucian dan penjernihan, kemudian diblok dengan parafin sesuai kode. Jaringan dipotong $\pm 3-5$ mikron. Potongan preparat jaringan direntangkan pada kaca objek, selanjutnya preparat diletakkan dalam oven selama $1-2$ jam pada suhu $60-70^{\circ} \mathrm{C}$. Kemudian preparat dimasukkan berturut-turut kedalam larutan xylol sebanyak dua kali, alkohol $96 \% 4$ kali masing-masing \pm 3 menit kemudian dicuci dengan air selama 10 menit. Selanjutnya, preparat dicat dengan hematoksilin selama 
15 menit kemudian dicuci dengan air mengalir selama 15 menit, dengan alkohol asam 1\%, dan amonia air. Kemudian, preparat dicat dengan eosin $1 \%$ dan dicuci dengan alkohol 80\%, alkohol 96\%, alkohol 96\%, dan dijernihkan dengan xylol. Terakhir, preparat ditutup kaca penutup (coverslip) dengan entelan.

\section{Pengukuran Kadar MDA}

Organ ditimbang sebanyak $10 \mathrm{mg}$, kemudian digerus sampai halus. Lalu, ditambahkan dengan aquades dan dimasukkan kedalam tabung appendorf. Homogenat ditambahkan TCA $100 \% 100 \mu \mathrm{L}$, tiobarbiturat Na 1\% $100 \mu \mathrm{L}, \mathrm{HCl} 1 \mathrm{~N} 250 \mu \mathrm{L}$. Campuran divortex hingga homogen dan diinkubasi selama 20 menit pada suhu $100^{\circ} \mathrm{C}$. Lalu, disentrifugasi pada kecepatan 3500rpm selama 10 menit. Diambil supernatan dan ditambahkan aquades $3500 \mu \mathrm{L}$ kemudian dimasukkan dalam kuvet. Diukur dengan spektrofotometri pada $\lambda 532 \mathrm{~nm}$ (18).

\section{Analisis Data}

Analisis data dilakukan dengan menggunakan uji beda Kruskal-Walis dan uji korelasi Pearson-product moment dan uji antar kelompok Mann-Whitney dengan SPSS versi 20.00 untuk analisis kadar MDA hati dan jumlah hepatosit yang mengalami perlemakan.

\section{HASIL}

\section{Kadar MDA Hati}

Kadar MDA kelompok DTA $(68,2 \pm 14,43)$ lebih tinggi dibandingkan kelompok NTA $(42,3 \pm 6,06)$. Kelompok perlakuan ALA DA80 $(56,5 \pm 17,8)$ dan DA200 $(62,5 \pm 17,99)$ menunjukkan kadar yang lebih rendah dibandingkan DTA. Uji normalitas dan homogenitas data menunjukkan sebaran data yang tidak normal sehingga dilakukan uji non parametrik menggunakan Kruskal-Wallis. Berdasarkan uji Kruskal-Wallis menunjukkan tidak ada perbedaan signifikan pada kadar MDA kelompok NTA, DTA, DA80, dan DA200 $(p=0,08)$. Pada uji korelasi Pearson-product moment menunjukan hubungan positif yang cukup kuat, namun tidak signifikan $(r=0,440, p=0,67)$ antara kelompok NTA, DTA, DA80, dan DA200 dengan kadar MDA. Data kadar MDA pada hati tikus dapat dilihat pada Gambar 1.

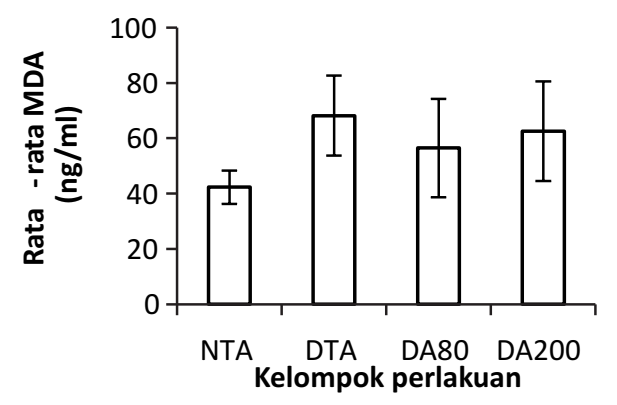

Gambar 1. Kadar MDA pada hati tikus.

Keterangan: Peningkatan kadar MDA DTA dibandingkan NTA dan penurunan kadar MDA DA80 dan DA200 dbandingkan DTA, namun tidak ada perbedaan signifikan antar kelompok.

\section{Pengamatan Makroskopik}

Pengamatan yang dilakukan, yaitu pengamatan terhadap warna hati tikus (Gambar 2). Hasil pengamatan tersebut menunjukkan adanya perbedaan warna hati antar kelompok perlakuan. Pengamatan warna dilakukan menggunakan Faber Castell (19). Hati kelompok NTA berwarna merah kecoklatan (caput mortum, kode warna: 169), sedangkan hati kelompok DTA berwarna merah pucat (darkflesh, kode warna: 130).

Kelompok perlakuan DA80 dan DA200 memiliki warna hati yang mendekati warna hati NTA, namun terlihat lebih coklat (walnut brown, kode warna: 177). Kelompok perlakuan DA500 memiliki hati yang berwarna lebih pucat mendekati warna putih dibandingkan dengan DTA (light flesh, kode warna: 132). Ditemukan kelainan yang ditunjukkan dengan benjolan putih dan warna hati merah yang lebih pudar dibandingkan tikus normal.

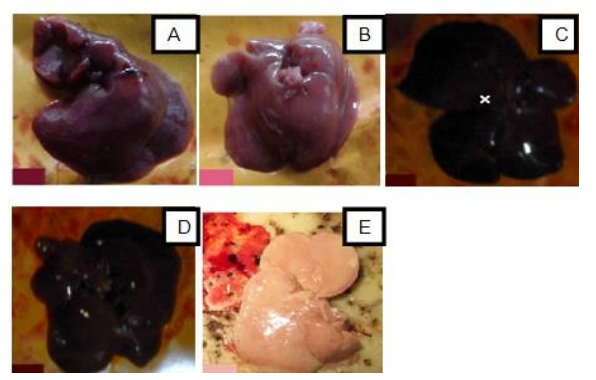

Gambar 2. Pengamatan makroskopik.

Keterangan: (A) NTA; (B) DTA); (C) DA80; (D) DA200; (E) DA500. Warna hati DTA lebih pudar dibandingkan NTA. DA80 dan DA200 menunjukkan warna merah kecoklatan mendekati warna NTA.

\section{Gambaran Histologi Hati Tikus}

Pada kelompok NTA (Gambar 3A) menunjukkan gambaran vena sentral yang dikelilingi sel hepatosit dan sinusoid yang tersusun secara radial. Gambar histologi hati DTA (Gambar 3B), terlihat perlemakan pada hepatosit yang dekat dengan vena sentralis, sinusoid nampak tidak teratur, hipertrofi hepatosit, dan infiltrasi limfosit. Kelompok DA80 (Gambar 3C), mulai nampak perbaikan pada hepatosit dan sinusoid. Gambaran morfologi hepatosit menyerupai kelompok normal dan mengalami penurunan jumlah hepatosit yang mengalami perlemakan. Kelompok DA200 (Gambar 3D), terjadi perbaikan hepatosit dan sinusoid sama seperti DA80 dan mendekati kelompok NTA. Ukuran hepatosit tampak lebih bervariasi dibandingkan NTA. Pada hepatosit yang mengalami perlemakan makrovesikuler isi hepatosit terdorong keluar sehingga terlihat vakuola yang kosong, besar sel bervariasi, sitoplasmanya tampak jernih dan inti sel berada di tepi (20).

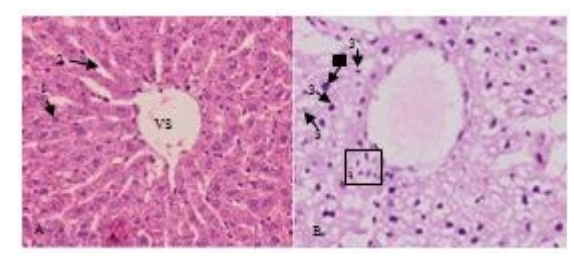

Gambar 3. Histologi hati dengan pewarnaan HE (perbesaran 100x)

Keterangan:

(A) NTA; (B) DTA; (C) DA80; (D) DA200; (E) DA500; (F) Infiltasi limfosit pada DTA dengan perbesaran $200 \mathrm{X}$ dari gambar $\mathrm{B}$ (i) 


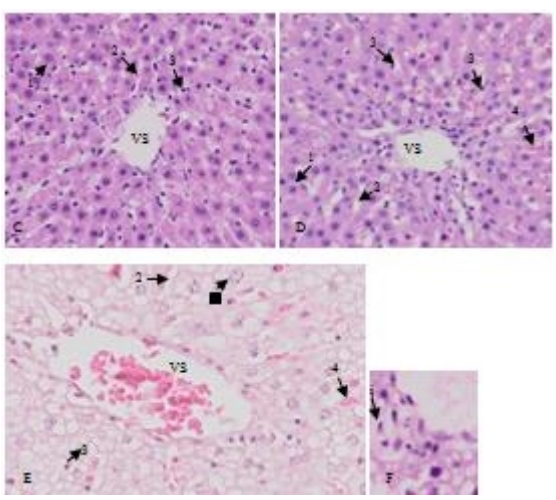

Gambar 3. Histologi hati dengan pewarnaan HE (perbesaran 100x) (Lanjutan)

Keterangan: (A) NTA; (B) DTA; (C) DA80; (D) DA200; (E) DA500; (F) Infiltasi limfosit pada DTA dengan perbesaran 200X dari gambar B (I)

1 = hepatosit normal, 2 = sinusoid,

3 = hepatosit mengalami perlemakan,

4 = pembendungan darah pada sinusoid,

= hipertropi hepatosit, VS = vena sentralis

= inset pembesaran 200x infiltrasi limfosit

Pada kelompok DA200 menunjukkan penurunan jumlah hepatosit yang mengalami perlemakan dibandingkan DTA, lebih banyak dibandingkan NTA, dan terlihat sama dengan DA80. Pada gambaran histologi hati tersebut, terdapat sinusoid-sinusoid yang terisi darah ditunjukkan dengan warna merah terang yang lebih banyak dibandingkan NTA, DTA, dan DA80. Gambar kelompok DA500 (Gambar 3E), hepatosit dan sinusoid mengalami kerusakan seperti kelompok DTA. Adanya hipertrofi hepatosit, perlemakan pada hepatosit, pembendungan aliran darah pada vena sentralis dan sinusoid. Pembendungan tersebut ditandai dengan massa yang berwarna merah terang (19).

\section{Pemeriksaan Jumlah Perlemakan pada Hepatosit}

Jumlah hepatosit yang mengalami perlemakan pada DTA $(108 \pm 51,2)$ lebih tinggi dibandingkan NTA $(26 \pm 7,9)$ dan kelompok perlakuan ALA. Kelompok perlakuan ALA pada DA80 $(50,8 \pm 20)$ dan DA200 $(76,8 \pm 5,6)$ menunjukkan penurunan hepatosit yang mengalami perlemakan dibandingkan DTA. Perbedaan antara empat kelompok ditunjukkan oleh derajat perlemakan pada hepatosit, seperti pada Gambar 4.

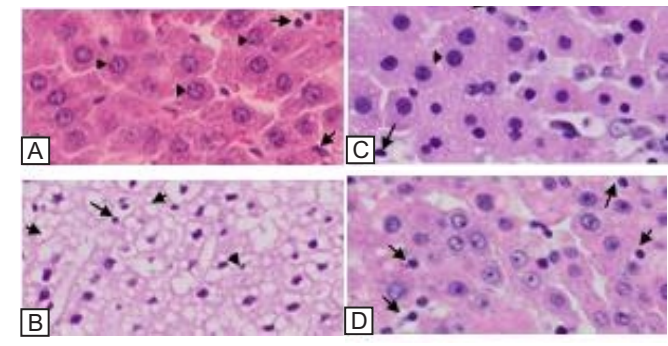

Gambar 4. Gambaran hepatosit yang normal dan yang mengalami perlemakan dengan pengecatan $\mathrm{HE}$ dan pembesaran $400 \mathrm{X}$

Keterangan:

(A) NTA; (B) DTA; (C) DA80; (D) DA200

$\rightarrow$ : Hepatosit normal

$\rightarrow$ : Hepatosit yang mengalami perlemakan
Pada uji korelasi Pearson-Product-Moment terdapat hubungan positif yang cukup kuat, namun tidak signifikan $(r=0,429, p=0,89)$. Lalu, hasil uji Kruskal-Wallis menunjukkan data signifikan $(p=0,008)<0,05$. Sementara, hasil uji Mann-Whitney menunjukkan perbedaan signifikan antara kelompok NTA dengan DTA dan DA200 (NTA vs DTA $p=0,02 ;$ NTA vs DA200 $p=0,011$ ). Tidak ada perbedaan signifikan antara kelompok DTA dengan kelompok DA80 dan DA200 (DA80 vs DTA p=0,077, DA200 vs DTA $p=0,480$ ), antara kelompok DA80 dan DA200 (DA80 vs DA200 $p=0,111)$, dan antara kelompok NTA dan DA80 (NTA vs DA80 $p=0,42$ ). Diagram rata-rata jumlah perlemakan pada hepatosit ditunjukkan pada Gambar 5.

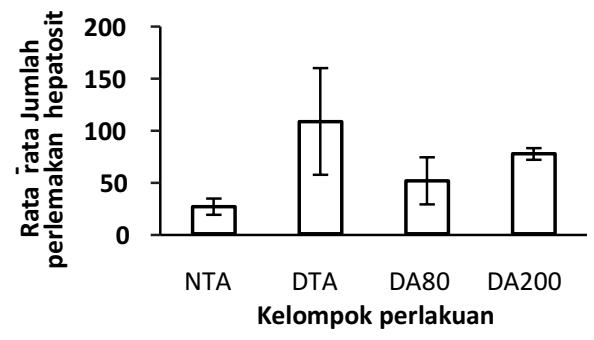

Gambar 5. Diagram rata-rata hepatosit (sel hati) yang mengalami perlemakan.

\section{DISKUSI}

\section{Pengaruh ALA terhadap Kadar MDA}

Pada penelitian ini, pemberian ALA dosis $80 \mathrm{mg} / \mathrm{kg}$ dan $200 \mathrm{mg} / \mathrm{kg}$ menunjukkan penurunan kadar MDA hati dibandingkan tikus diabetes, namun lebih tinggi dibandingkan kelompok normal. Penurunan kadar MDA mungkin disebabkan oleh peran ALA sebagai scavenger senyawa oksigen reaktif (ROS), senyawa nitrogen reaktif (RNS) seperti asam hipokloro (HOCL), radikal hidroksil, radikal peroksil, superoksida, dan peroksinitrit (21). Perbedaan yang tidak signifikan, mungkin disebabkan oleh sistem pertahanan enzimatik (superoksida dismutase, glutation peroksida GPx, glutation reduktase, dan katalase) dan nonenzimatik (glutation GSH, thioredoksin, asam lipoat, ubiquinol, vitamin $A$, vitamin E) dalam melawan radikal oksigen bebas $(1,22)$. Kemungkinan lainnya yaitu MDA dilepaskan pada proses peroksidasi lipid pada jaringan hati dimetabolisme secara cepat oleh mitochondrial MDA-metabolizing enzyme (aldehid dehidrogenase) dan peningkatan kadar MDA tidak terlihat (23). Perbedaan jangka waktu antara penelitian ini (4 minggu) dibandingkan dengan penelitian sebelumnya 8 minggu, 24 minggu, dan 60 hari) mungkin mempengaruhi hasil signifikansi kadar MDA $(11,23)$.

\section{Pengaruh ALA terhadap Pengamatan Makroskopik Hati}

Terdapat perbedaan warna hati antara tikus normal, diabetes, dan pemberian perlakuan ALA. Hati tikus normal (NTA) berwarna merah kecokelatan karena mengandung darah yang difasilitasi oleh banyaknya pembuluh darah, yaitu arteri hepatika dan vena porta hepatika. Warna hati merah pucat pada kelompok DTA kemungkinan disebabkan gangguan aliran darah pada hati yang disebabkan oleh diabetes. Pada kondisi hiperglikemi, terjadi proses peroksidasi lipid dan aktivasi faktor 
transkripsi faktor nuklear-kB (NF-kB) yang menyebabkan terjadinya kerusakan hati dan fibrogenesis (24-26). Fibrosis menyebabkan kapilarisasi sinusoid dan mengganggu pertukaran zat terlarut antara ruang sinusoid dan hepatosit (27). Hal tersebut diduga merupakan penyebab warna hati yang pucat. Pada penelitian ini tidak dilakukan pengamatan fibrosis pada hati.

Hasil pengamatan warna hati pada kelompok perlakuan pemberian ALA menunjukkan adanya perubahan warna menjadi merah kecoklatan mendekati warna normal. Kemungkinan hal tersebut disebabkan efek ALA terhadap sirkulasi darah. Pada penelitian ini, perubahan warna hati bukandisebabkan penurunan stres oksidatif, karena kadar MDA tidak menunjukkan perbedaan bermakna antar perlakuan. ALA menghambat aktivasi NF-kB (9). Aktivasi NF-kB memicu terjadinya inflamasi dan fibrogenesis (25). Namun, pada DA500 menunjukkan warna yang lebih pucat dibandingkan warna DTA. Hal tersebut mungkin disebabkan oleh gangguan aliran darah pada hati tikus.

\section{Pengaruh ALA terhadap Gambaran Histologi Hati Tikus}

Pada tikus normal, terdapat sebuah vena sentral di setiap pusat lobulus yang dikelilingi sel hepatosit dan sinusoid. Pada tikus diabetes terjadi, hipertrofi hepatosit akibat bereaksi terhadap toksin, ROS, iskemi dengan mengaktivasi mekanisme pertahanan termasuk hipertrofi retikulum endoplasma dan induksi sistem protektif (glutation, GSH) (28). Pembengkakan hepatosit mengakibatkan sinusoid menyempit dan aliran darah terganggu. Apabila aliran darah terganggu berlangsung lama, maka sel-sel hati tampak hilang karena gangguan penghantaran nutrisi. Kondisi ini menyebabkan hepatosit mengalami nekrosis yang kemudian menyebabkan terjadinya degenerasi vakuola. Degenerasi vakuola atau pembengkakan sel merupakan salah satu indikasi terjadinya perlemakan hati, pada keadaan ini hepatosit tampak membesar (29). Akumulasi lemak pada hepatosit disebabkan oleh peningkatan FFA (free fatty acid) kedalam hati akibat diabetes (30). Sel Kuppfer merupakan bagian dari jaringan makrofag yang berada dalam lumen sinusoid hati yang mengaktivasi dan melibatkan inflamasi dalam berbagai kerusakan hati. Inflamasi menyebabkan jaringan hati menampakkan infiltrasi limfosit (27).

Pada kelompok DA80 dan DA200 menunjukkan adanya penurunan perlemakan pada hepatosit, sinusoid mulai nampak jelas, dan penurunan infiltrasi limfosit dibandingkan kelompok DTA. Pada DA200 terjadi pembendungan darah pada sinusoid diakibatkan oleh perlemakan pada sel hati yang menyebabkan kongesti hati. Kongesti hati menyebabkan perubahan mikrosirkulasi pada hati yang mengakibatkan perubahan hemodinamik dan sistemik, obstruksi lumen sinusoid, dan menjebak sel darah merah. Kerusakan sel hati dapat disebabkan akibat peningkatan produksi ROS maupun jalur inflamasi, seperti IL-6, NF-KB, dan TNF- $\alpha$ (31). Faktor transkripsi faktor nuklear-kB (NF-kB), merupakan regulator utama inflamasi dan kematian sel dalam pengembangan kerusakan sel hati (32). ALA menghambat jalur aktivasi NF-KB (33). Kemungkinan, hambatan NF-KB menghambat hipertrofi hepatosit, akumulasi lemak pada hepatosit, dan infiltrasi limfosit. Selain itu, ALA juga menghambat lipogenesis pada hati, sehingga menurunkan jumlah akumulasi lemak pada hati (34).
Pada tikus dengan ALA dosis $500 \mathrm{mg} / \mathrm{kg}$ terjadi perlemakan hati, sinusoid nampak tidak teratur menyerupai tikus diabetes, pembendungan darah pada sinusoid dan vena sentralis. Hal tersebut disebabkan oleh pembengkakan sel hati yang mengakibatkan sinusoid menyempit dan aliran darah terganggu, sama seperti yang terjadi pada tikus diabetes. Pembendungan darah pada sinusoid dan vena sentralis diakibatkan oleh pembengkakan hepatosit yang menyebabkan kongesti hati (29). Kongesti dapat disebabkan oleh gangguan aliran darah dari jantung yang menyebabkan pembuluh darah melebar dengan aliran darah yang melambat sehingga darah membendung di jaringan berkumpul membentuk pembendungan di pembuluh darah (35). Pada ALA dosis $500 \mathrm{mg} / \mathrm{kg}$ menunjukkan keparahan gambaran histologi hati, kemungkinan disebabkan oleh dosis respon ALA terhadap diabetes.

\section{Pengaruh ALA terhadap Jumlah Perlemakan pada Hepatosit}

Peningkatan glukoneogenesis dan peningkatan lipolisis dengan menghasilkan asam lemak bebas yang menyebabkan peningkatan pengambilan FFA, sintesis dan akumulasi trigliserida. Nonalcoholic fatty liver disease (NAFLD) merupakan kelainan hati yang biasanya terjadi pada diabetes dengan akumulasi lemak dalam hepatosit tanpa inflamasi atau fibrosis (simple steatosis) yang dapat berkembang menjadi steatosis dengan nekroinflamasi dengan fibrosis ataupun sirosis (36).

Penurunan perlemakan pada hepatosit setelah pemberian ALA dosis 80 dan $200 \mathrm{mg} / \mathrm{kg} /$ hari kemungkinan disebabkan efek ALA yang menghambatsterol regulatory element binding protein-1C (SREBP-1C), gen yang mengatur transkripsi lipogenesis pada hati dan menghambat NF-KB (mediator inflamasi) (37). Pemberian ALA pada dosis 200 $\mathrm{mg} / \mathrm{kg}$ lebih tinggi dibandingkan dosis $80 \mathrm{mg} / \mathrm{kg}$. Hal tersebut menunjukkan adanya respon dosis ALA terhadap perlemakan pada hepatosit.

Tikus diabetes dengan terapi ALA dosis $500 \mathrm{mg} / \mathrm{kg}$ mati dalam waktu beberapa hari terapi. LD $_{50}$ terjadi pada dosis lebih dari $2000 \mathrm{mg} / \mathrm{kg}$ berat badan. Pada dosis 2000 $\mathrm{mg} / \mathrm{kg}$ berat badan, tikus menunjukkan tanda-tanda sedasi, piloereksi, lesu, membungkuk, dan mata tertutup. Pada penelitian ini tikus dengan dosis $500 \mathrm{mg} / \mathrm{kg}$ berat badan tidak menunjukkan tanda-tanda tersebut (38). Kematian yang terjadi pada kelompok DTA kemungkinan disebabkan oleh peningkatan stres oksidatif akibat hiperglikemia yang merusak jaringan jantung dan diikuti kondisi iskemia. Mortalitas yang terjadi pada DA80, DA200, dan DA500 kemungkinan disebabkan efek ALA mengaktivasi MAPK p38 (Mitogen Activated Protein Kinase) yang meningkatkan ambilan glukosa ke dalam sel. Pada kondisi iskemia, MAPK p38 menstimulasi glikolisis dan oksidasi asam lemak yang memperburuk penyembuhan setelah kondisi iskemia. Hal ini disebabkan peningkatan oksidasi asam lemak menekan oksidasi glukosa dan proses glikolisis tetap berlanjut sehingga terjadi ketidakseimbangan antara glikolisis dan oksidasi glukosa yang menyebabkan produksi proton sitosolik dan asidosis intraselular (3).

Pengaruh stres oksidatif akibat diabetes pada penelitian ini ditandai dengan peningkatan kadar MDA hati pada kelompok diabetes dibandingkan kelompok normal, meskipun tidak ada perbedaan secara statistik. Selain itu, stres oksidatif juga ditunjukkan dengan perubahan 
struktur dari gambaran histologi hati tikus dan peningkatan jumlah perlemakan hepatosit secara signifikan.

Hubungan dosis respon pada penelitian penggunaan ALA masih perlu dilakukan untuk mengetahui keterkaitan antara dosis respon dan dosis efektif untuk perbaikan pada kerusakan hati akibat DM tipe 1. Keparahan penyakit berpengaruh terhadap dosis ALA yang ditoleransi oleh tikus diabetes (10). ALA mungkin berpengaruh dalam pengembangan diabetes maupun komplikasi pada hati, seperti NAFLD dan NASH, namun pemilihan dosis,

\section{DAFTAR PUSTAKA}

1. Mohora M, Greabu M, Muscurel C, Duta C, and Totan A. The Sources and the Targets of Oxidation Stress in the Etiology of Diabetic Complication. Romanian Journal of Biophysics, 2007; 17(2): 63-84.

2. Zhu W, Minli C, Qiyang S, Li Y, and Hu F. Biological Activities of Chinese Propolis and Brazilian Propolis on Streptozotocin-Induced Type 1 Diabetes Mellitus in Rats. Evidence-Based Complementary and Alternative Medicine. 2011; 2011: 8.

3. Fatmawati NA, Lyrawati D, and Yurina V. Effect of Alpha Lipoic Acid on Oxidative Stress in Heart of Male Wistar Rats with Type I Diabetes Mellitus Model Induced by Streptozotocin. $6^{\text {th }}$ Asian Association of Schools of Pharmacy Conference Program and Abstracts Book. Singapore, 14-17 November 2013; 183.

4. Moussa SA. Oxidative Stress in Diabetes Mellitus. Romanian Journal of Biophysics. 2008; 18(3): 225236.

5. Herawati, Aulanni'am, dan Sasangka P. Peran Terapi d-alfa Tokoferol terhadap Kadar Glukosa Darah dan Kadar MDA (Malondialdehid) pada Tikus Diabetes Melitus Tipe 1 Hasil Induksi MLD-STZ. Veterinaria Medika, 2012; 5(3): 195-200.

6. Abolfathi AA, Mohajeri D, Rezaie A, and Nazeri M. Protective Effects of Green Tea Extract against Hepatic Tissue Injury in Streptozotocin-Induced Diabetic Rats. Evidence-Based Complementary and Alternative Medicine. 2012; 2012: 10.

7. Dias AS, Porawski $M$, Alonso $M$, Marroni $M$, Collado PS, and Gonzalez-Gallego J. Biochemical and Molecular Actions of NutrientsQuercetin Decreases Oxidative Stress, NF-KB Activation, and iNOS Overexpression in Liver of Streptozotocin-Induced Diabetic Rats. The Journal of Nutrition. 2005; 135(10): 2299-2304.

8. Johansen JS, Harris AK, Rychly DJ, and Ergul A. Oxidative Stress and the Use of Antioxidants in Diabetes: Linking Basic Science to Clinical Practice. Cardiovascular Diabetology. 2005; 4: 5.

9. Golbidi S, Badran M, and Laher I. Diabetes and Alpha Lipoic Acid. Frontiers in Pharmacology. 2011; 2: 15.

10. Maritim AC, Sanders RA, and Watkins JB. Effects of ALipoic Acid on Biomarkers of Oxidative Stress in Streptozotocin-Induced Diabetic Rats. Journal of Nutritional Biochemistry, 2003; 14(5): 288-294.

11. Taha N, Korshom M, Mandour AW, and Sadek K. Lipoic keparahan penyakit, dan lama waktu pemberian berpengaruh dalam keberhasilan terapi ALA.

Pemberian ALA dosis 80 dan $200 \mathrm{mg} / \mathrm{kg} /$ hari menunjukkan perbaikan gambaran histologi, warna hati, dan penurunan jumlah perlemakan hepatosit, namun tidak memberikan pengaruh terhadap peningkatan kadar MDA hati dibandingkan tikus diabetes. Pada dosis ALA tertinggi, $500 \mathrm{mg} / \mathrm{kg} / \mathrm{hari}$ menunjukkan perubahan warna hati lebih pucat dibandingkan tikus diabetes, peningkatan jumlah perlemakan hepatosit yang serupa dengan tikus diabetes, dan tingkat kematian yang lebih tinggi.

Acid Impedes Markers of Oxidative Stress in the Liver of Streptozotocin-Diabetic Rats. Global Journal of Medicinal Plant Research. 2013; 1(2): 195-198.

12. Shotton HR, Clarke $S$, and Lincoln J. The Effectiveness of Treatments of Diabetic Autonomic Neuropathy is Not the Same in Autonomic Nerves Supplying Different Organs. Diabetes. 2003; 52: 157-164.

13. Lee JE, Yi C, Jeon BT, et al. Alpha-lipoic Acid Attenuates Cardiac Fibrosis in Otsuka Long-Evans Tokushima Fatty rats. Cardiovascular Diabetology. 2012; 11: 10.

14. El Midaoui A and de Champlain J. Prevention of Hypertension, Insulin Resistance, and Oxidative Stress by $\alpha$-Lipoic Acid. Hypertension. 2002; 39(2): 303-307.

15. Li C, Lv L, Li H, and Yu D. Cardiac Fibrosis and Dysfunction in Experimental Diabetic Cardiomyopathy are Ameliorated by Alpha-lipoic Acid. Cardiovascular Diabetology. 2012; 11: 73.

16. Konuk M, Sahin T, Cigerci IH, Fidan AF, and Korcan SE. Efects of $\alpha$-lipoic Acid on DNA Damage, Protein Oxidation, Lipid Peroxidation, and Some Biochemical Parameters in Sub-chronic Thinner-addicted Rats. Turkey Journal of Biology. 2012; 36: 702-710.

17. American Veterinary Medical Association. AVMA Guidelines on Euthanasia: 2007 Edition. (Online). www.avma.org/issues/animal_welfare/euthanasia.p df [diakses tanggal 20 Januari2013].

18. Aulanni'am, Roosdiana A, and Rahmah NL. The Potency of Sargassum duplicatum Bory Extract on Inflammatory Bowel Disease Therapy in Rattus norvegicus. Journal of Life Sciences. 2012; 6(2): 144154.

19. Kaniawati SD. Uji Potensi Hepatoprotektif Senyawa Dimer Dari Isoeugenol terhadap Histologi Hati Mencit (Mus Musculus) Jantan Galur DDY. [Skripsi]. Universitas Indonesia, Depok. 2012.

20. Mahlianoor M. Pengaruh Pemberian Quercetin terhadap Perlemakan Hati pada Hati Tikus Putih (Rattus Novergicus Strain Wistar) yang Diberi Diet Aterogenik. [Tugas Akhir]. Universitas Brawijaya, Malang. 2009.

21. Islam MT. Antioxidant Activities of Dithiol AlphaLipoic Acid. Bangladesh Journal of Medical Science. 2009; 8(3): 46-51.

22. Bukan N, Sancak B, Yavuz O, et al. Peroxidation and Scavenging Enzyme Levels in the Liver of Streptozotocin-Induced Diabetic Rats. Indian Journal of Biochemistry \& Biophysics. 2003; 40(6): 447-450. 
23. Söğüt $S$, Songur A, Özen OA, Özyurt H, and Sarsılmaz M. Does the Subacute (4-Week) Exposure to Formaldehyde Inhalation Lead to Oxidant/Antioxidant Imbalance in Rat Liver? European Journal of General Medicine. 2004; 1(3): 26-32.

24. Rolo AP and Palmeira CM. Diabetes and Mitochondrial Function: Role of Hyperglycemia and Oxidative Stress. Toxicology and Applied Pharmacology. 2006; 212(2): 167-178.

25. Manna P, Das J, Ghosh J, and Sil PC. Contribution of Type 1 Diabetes to Rat Liver Dysfunction and Cellular

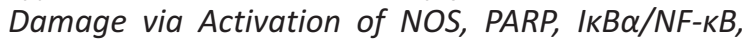
MAPKs, and Mitochondria-Dependent Pathways: Prophylactic Role of Arjunolic Acid. Free Radical Biology and Medicine. 2010; 48(11): 1465-1484.

26. Tessari P, Coracina A, Cosma A, and Tiengo A. Hepatic Lipid Metabolism and Non-Alcoholic Fatty Liver Disease. Nutrition, Metabolism, and Cardiovascular Diseases. 2009; 19(4): 291-302.

27. Deniz GY, Geyikoglu F, Türkez H, Bakir TO, Colak S, and Aslan A. The Biochemical and Histological Effects of Lichens in Normal and Diabetic Rats. Toxicology and Industrial Health. 2013; 2013:1-13.

28. Grattagliano I, Bonfrate L, Diogo CV, Wang HH, Wang $\mathrm{DQH}$, and Portincasa P. Biochemical Mechanisms in Drug-Induced Liver Injury: Certainties and Doubts. World Journal of Gastroenterology. 2009; 15(39): 4865-4876.

29. Sukarni S, Maftuch M, dan Nursyam H. Kajian Penggunaan Ciprofloxacin terhadap Histologi Insang dan Hati Ikan Botia (Botia macracanthus, Bleeker) yang Diinfeksi Bakteri Aeromonas hydrophila. The Journal of Experimental Life Science. 2012; 2(1): 6-12.

30. Liu F, Xie M, Chen D, Li J, and Ding W. Effect of (dipicCl) on Lipid Metabolism Disorders in the Liver of STZInduced Diabetic Rats. Journal of Diabetes Research.
2013; 2013: 10.

31. Starley BQ, Calcagno CJ, and Harrison SA. Nonalcoholic Fatty Liver Disease and Hepatocellular Carcinoma: A Weighty Connection. Hepatology. 2010; 51(5): 1820-1832.

32. Luedde $T$ and Schwabe RF. NF-Kb in the Liver-Linking Injury, Fibrosis and Hepatocellular Carcinoma. Nature Reviews Gastroenterology \& Hepatology. 2011; 8(2): 108118.

33. Lee CK, Lee EY, Kim YG, Mun SH, Moon HB, and Yoo B. Alpha-Lipoic Acid Inhibits TNF-A Induced NF-Kb Activation Through Blocking of MEKK1-MKK4-IKK Signaling Cascades. International Immunopharmacology. 2008; 8(2):362-370.

34. Kuo YT, Lin TH, Chen WL, and Lee HM. Alpha-Lipoic Acid Induces Adipose Triglyceride Lipase Expression and Decreases Intracellular Lipid Accumulation in HepG2 Cells. European Journal of Pharmacology. 2012; 692(1-3): 10-18.

35. Aziza RZ. Gambaran Histomorfologi Hati, Usus Halus, dan Limpa Pada Tikus Hiperglikemia yang Diberi Ekstrak Sambiloto. [Skripsi]. Institut Pertanian, Bogor. 2010.

36. Krawczyk M, Leonilde B, and Piero P. Nonalcoholic Fatty Liver Disease. Best Practice \& Research Clinical Gastroenterology. 2010; 24(6): 695-708,

37. Park KG, Min AK, Koh EH, et al. Alpha-Lipoic Acid Decreases Hepatic Lipogenesis through Adenosine Monophosphate Activate Protein Kinase (AMPK)Dependent and AMPK-Independent Pathways. Hepatology. 2008; 48(5): 1477-1486.

38. Shay KP, Moreau RF, Smith EJ, Smith AR, and Hagen TM. Alpha-lipoic Acid as a Dietary Supplement: Molecular Mechanisms and Therapeutic Potential. Biochimica et Biophysica Acta. 2009; 1790(10): 1149-1160. 